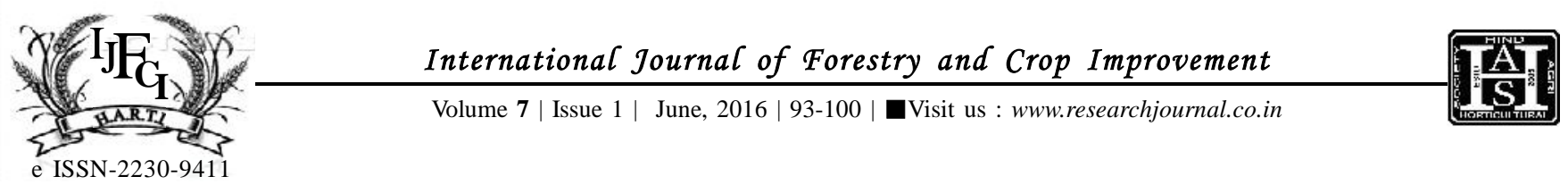

\title{
Genetic analysis and correlation studies for grain yield in rice (Oryza sativa L.) under the Allahabad agro climatic region
}

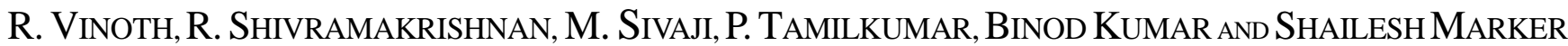

\begin{abstract}
An experiment was conducted to study the variability and association between characters in rice. 36 genotypes of rice were evaluated and obtain information on variability parameters and correlation analysis for 18 characters. Analysis of variance revealed high significant differences for all the 18 characters studied. Phenotypic co-efficient of variation (PCV) was higher than genotype co-efficient of variation (GCV) for all the characters indicating the little influence of environment on the characters. Number of unfilled grains per panicle had maximum GCV followed by grain yield per plant, harvest index, biological yield per plant, number of filled grains per panicle and grain L/B ratio. All the qualitative characters depicted high estimates of heritability, which indicates preponderance of additive gene action in the inheritance of these characters. High to moderate degree of genetic advance was observed for number of filled grains per panicle followed by biological yield per plant. Grain yield per plant showed positive and significant correlation with number of filled grains per panicle followed by harvest index, biological yield per plant and panicle length at phenotypic and genotypic level. Thus, these characters may serve as effective selection parameters during breeding programme for crop improvement.
\end{abstract}

KEY WORDS : Variability, Heritability, Genetic advance, Correlation analysis, Rice

HOW TO CITE THIS ARTICLE : Vinoth, R., Shivramakrishnan, R., Sivaji, M., TamilKumar, P., Kumar, Binod and Marker, Shailesh (2016). Genetic analysis and correlation studies for grain yield in rice (Oryza sativa $\mathrm{L}$.) under the Allahabad agro climatic region. Internat. J. Forestry \& Crop Improv., 7 (1) : 93-100, DOI: 10.15740/HAS/IJFCI/7.1/93-100.

Article Chronical : Received : 17.02.2016; Revised : 20.04.2016; Accepted : 21.05.2016

\section{MEMBERS OF RESEARCH FORUM}

Address of the Correspondence : R. VINOTH, Center for Plant Breeding and Genetics,

Tamil Nadu Agricultural University, COIMBATORE (T.N.) INDIA

Email: rvinothagri@gmail.com

Address of the Coopted Authors : R. SHIVRAMAKRISHNAN, Division of Plant Physiology, Indian Agricultural Research Institute, NEW DELHI, INDIA

M. SIVAJI, Department of Plant Biotechnology, Tamil Nadu Agricultural University, COIMBATORE (T.N.) INDIA

P. TAMILKUMAR, Department of Seed Science and Technology, Tamil Nadu Agricultural University, COIMBATORE (T.N.) INDIA

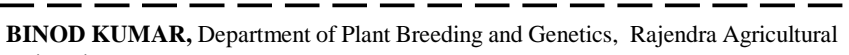
University, PUSA SAMASTIPUR (BIHAR) INDIA

SHAILESH MARKER, Department of Genetics and Plant Breeding, Allahabad School of Agriculture, Sam Higginbottom Institute of Agriculture Technology and Sciences, ALLAHABAD (U.P.) INDIA 